\title{
CMIWORKINGPAPER
}

\section{Regional Variation in Livelihood Strategies in Malawi}

\author{
Magnus Hatlebakk
}

WP 2009: 6 



\title{
Regional Variation in Livelihood Strategies in Malawi
}

\author{
Magnus Hatlebakk
}

WP 2009: 6 


\section{Working Papers}

This series can be ordered from:

Chr. Michelsen Institute

P. O. Box 6033 Postterminalen,

$\mathrm{N}-5892$ Bergen, Norway

Tel: +4755574000

Fax: + 4755574166

E-mail: cmi@cmi.no

www.cmi.no

Price: NOK 50

Printed version: ISSN 0804-3639

Electronic version: ISSN 1890-5048

Printed version: ISBN 978-82-8062-361-4

Electronic version: ISBN 978-82-8062-362-1

This report is also available at:

www.cmi.no/ publications

\section{Indexing terms}

Livelihoods

Non-farm employment

Multinomial-logit

Malawi

J EL-classification: D130, 0120, Q120

\section{Project title}

NFR Welfare

\section{Project number}

25010 


\section{Contents}

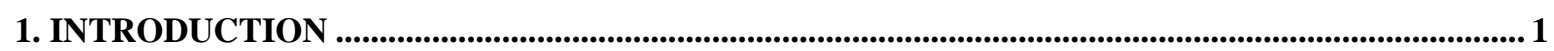

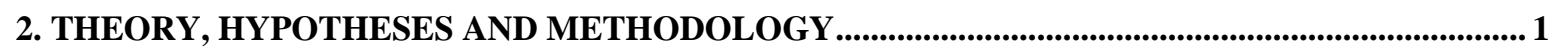

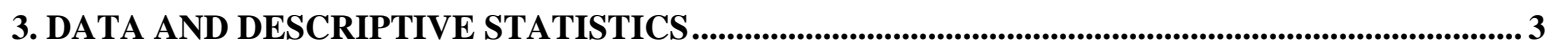

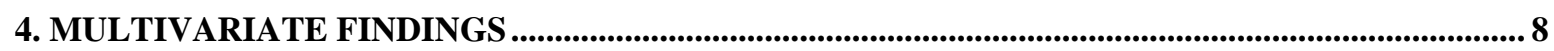

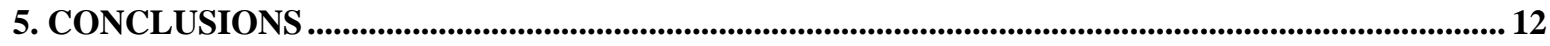

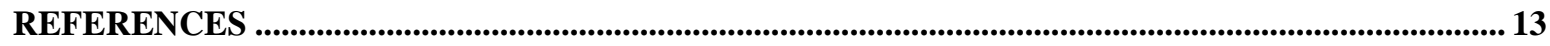





\title{
Regional Variation in Livelihood Strategies in Malawi*
}

\author{
by \\ Magnus Hatlebakk \\ Chr. Michelsen Institute, Norway \\ magnus.hatlebakk@cmi.no
}

\begin{abstract}
We identify livelihood strategies at the household level as a function of assets held, using survey data from Malawi. We only include endowments that we expect to be predetermined. As expected, land, household size, age and primary education are important determinants of livelihood strategies. It also turns out to be significant regional variation in livelihood strategies, with more diversification in the Southern region, and with regional variation in the role of ethnic and religious identity as determinants of livelihood strategies.
\end{abstract}

Keywords: Livelihoods, Non-farm employment, Multinomial-logit JEL-classification: D130, O120, Q120

\footnotetext{
* Thanks go to Charles Machinjili, Willie Kachaka and Berit Otnes at the National Statistical Office of Malawi for help with the data. Thanks also go to Mikkel Barslund and other participants at the Nordic Conference in Development Economics, Eyolf Jul-Larsen and other participants in the "Well-being among Fisherfolks in Africa" team, and Arne Wiig for useful discussions. The research is funded by the Research Council of Norway.
} 



\section{Introduction}

An obvious pathway out of poverty for poor households in agricultural based economies like Malawi is to supplement agricultural incomes with non-farm economic activities. The problem for policy makers, as well as researchers, is to identify factors that may enable the poor to leave the poverty trap that subsistence agriculture represents. We know that lack of assets, education and other endowments explain why households have to survive on small plots of land, or with no land at all as farm laborers. But why are some households able to accumulate assets, while others are not, and what are the links between assets and livelihood strategies? An empirical problem is that the assets a household have today may be the result of their livelihood strategy, and not the other way around. Farmers need animals and ploughs, shop-keepers need stores, and doctors need medical degrees. In these cases they already have, or they know almost for sure that they will get, a specific occupation when they make the investment. We want to go behind these simple mechanisms, and measure endowments that are likely to predetermine the present occupations of the household members. We have information on early endowments from a household survey. In particular we know whether someone in the household has the primary school living certificate, and we know the ethnic and religious identity of the household, as well as the gender and age of the household head.

But there are some other factors that are not immediately linked to an occupation, and not fully predetermined, but still are important determinants of the occupational mix of a household. These are in particular land- and household-size, as well as the geographical location of the household. Those factors are to some extent influenced, via reverse causality, by the choice of livelihood strategy, or they are affected by unobserved factors that also affect the livelihood strategy. Still, they are essential in understanding the occupational choices of household members, and are to a large extent decided upon prior to the occupational choice. That is, we believe the first-order-effects of these variables to dominate any reverse causality or unobserved factors. These presumptions will be discussed in more detail in section 2, where we also discuss some theoretical explanations for livelihood diversification. Then we present our data in section 3, including descriptive statistics on livelihood strategies. Section 4 presents the multivariate analysis, while section 5 concludes.

\section{Theory, hypotheses and methodology}

In rural economies agriculture is the basic occupation where people either work on their own land, or on other people's land as tenants or farm laborers. With agriculture as the basis, there are a number of diversification strategies, which to some extent will depend on the households' endowments. Among the poor some household members work as manual laborers on a day-to-day or permanent basis. In particular in Southern Malawi it appears that longer term wage contracts are common. Other poor households start low-scale household businesses, where they may be able to accumulate capital. Households with additional resources may invest in education in hope of getting better paid permanent jobs for their children, or they may invest in businesses. So households diversify to handle uncorrelated risk, but maybe more importantly they diversify to escape poverty. For more details on the different motives for diversification, see Barrett, Reardon and Webb (2001). We will conduct an empirical analysis where we first identify the main economic activities as casual labor, permanent wage labor, household businesses and agriculture, and then investigate to what extent endowments determine different combinations of these activities. In particular we expect households with limited endowments to combine agriculture with casual labor. The research is based on previous work by, in particular, Barrett, Bezuneh and Aboud (2001), Dorward et al. (2004), and Ellis, Kutengule and Nyasulu (2003), but ours is the first analysis we know of livelihood strategies in Malawi using the IHS2 survey data. 
As discussed in the introduction, some of the main determinants of livelihood strategies are potentially endogenous, and we will now discuss these potential biases in more detail, first land and then household size and geographical location. In Malawi it appears that land is accumulated first of all through political processes ${ }^{1}$. If we omit inherited plots (55\%) and plots received from the family or spouse (21\%), then the majority (22\%) of the plots are granted by local leaders, while only a small share (2\%) is purchased. If you are politically connected, then the costs of securing the right to a plot of land may be relatively low, as compared to the market price. So it is reasonable to argue that if a household get the chance it will secure the right to a plot of land, independently of what other occupations are planned for the household members. If this is so, then landholdings are determined prior to the choice of livelihood strategy. Still there may be some unobservable household characteristics that affect how connected you are with local leaders, and thus, in turn, how much land you may accumulate, and maybe also how likely it is that you get a well paid salaried job. If this is the case, then there will still be a problem of endogeneity. As a result the estimated coefficient for land will reflect both the direct effect of having land on occupational choice (larger probability of farming), as well as an indirect effect of political influence, as households with more land may be politically connected and thus have a higher probability of, in particular, salaried jobs.

Next, there will be a correlation between the occupational mix and the number of household members. In the survey most (approximately 85\%) of the household members are living in a nucleus family consisting of two parents and their children, which implies that most of the variation in household size is explained by the number of children that live with their parents. This in turn depends on the number of children born and the number of children that have separated and established their own household. Now the decision to split from the parents may be a function of occupational choice. In particular one may expect that boys who get a non-farm job will establish their own household. This is in support of the primary hypothesis that larger households will have more occupations. But we have to keep in mind that diversification may lead to smaller households as children separate from their parents, an effect that cannot be studied with the use of our data. Similarly there is a two-way correlation between occupational choice and geographical location. Not all occupations are easily available everywhere, which may lead households to migrate to other areas to be able to have a particular occupation.

So we include some determinants of occupational choice that are obviously endogenous, in the sense that they are either a function of the choice of occupation, or influenced by non-observable factors, such as political influence, that also affects occupational choice. We still include these variables (land, household-size, and location) in the analysis because we believe the first-order-effects to be essential in understanding the variation in occupational choice between households. If we omit those variables, then the analysis will be misleading. As we do not have any good instrument that may affect land, household-size and migration, but not occupational choice, we have to report the potentially biased estimates, and rather keep in mind the possible feedback mechanisms and unobservable factors that we have discussed above. The motivation for the analysis is to identify empirical regularities, but not to base policy prescription on the estimated coefficients. We can, for example, not use the findings to predict the effect of a redistribution of land on livelihood diversification. But we may be able to say that households with more land diversify more, and we may be able to explain why.

Note that we have been relatively restrictive when it comes to what independent variables to include, as we do not include farm assets other than land, and not occupational history, or any higher education. This is to avoid explanatory variables that we know are highly correlated with the dependent variable but do not add insights on why the particular livelihood strategy is chosen. We know that a farmer will need farm assets, a carpenter will tend to be a carpenter some years down the road, and a doctor will have a medical degree, but this does not add to our understanding of why people are farmers, carpenters or doctors. With relatively few independent variables that are determined even years prior to the household survey, we may expect a low (pseudo) R-squared in our (multinomial-logit) analysis. This means that unobservable household characteristics, such as motivation and talent, as well as unobserved events may explain a large amount of the variation in

\footnotetext{
${ }^{1}$ Although this is debated, see Jul-Larsen and Mvula (2009).
} 
livelihood strategies. Still there may be some systematic variation in the data that can be utilized to identify empirical regularities that may constitute the basis for policy prescriptions.

\section{Data and descriptive statistics}

We apply the second round of the Integrated Household Survey of Malawi, see IHS2 (2005), which appears to be a high quality data source. In total 11280 households were interviewed. We will focus on the rural population, excluding also smaller urban centers, and we thus have a rural sample of 9100 households. The main occupations of the household heads are listed in Table 1.

Table 1: Main activity of household head

\begin{tabular}{|l|rrr|rr|}
\hline $\begin{array}{l}\text { What has been your } \\
\text { main activity during } \\
\text { the past 7 days? }\end{array}$ & \multicolumn{2}{l}{$\begin{array}{l}\text { At any time in past 12 mos. } \\
\text { Were you employed for a wage? }\end{array}$} & & \multicolumn{2}{l|}{$\begin{array}{l}\text { In last 12 mos. Did you engage } \\
\text { in casual (ganyu) labor? }\end{array}$} \\
\hline Farmer(Mlimi) & \multicolumn{2}{l}{ Yes } & No & & No \\
Employee & 6012 & 586 & 5426 & 2550 & 3468 \\
Family business worker & 1041 & 996 & 45 & 175 & 862 \\
Self employed & 429 & 35 & 394 & 117 & 312 \\
Employer & 498 & 53 & 445 & 132 & 366 \\
Unemployed & 34 & 30 & 4 & 2 & 32 \\
Non worker & 102 & 18 & 84 & 45 & 57 \\
Homeworker & 61 & 2 & 59 & 14 & 47 \\
Student & 312 & 23 & 289 & 108 & 204 \\
Other & 18 & 4 & 14 & 3 & 15 \\
No response & 507 & 62 & 445 & 303 & 204 \\
\hline Total & 21 & 1 & 20 & 4 & 16 \\
\hline
\end{tabular}

As the interviews were spread evenly over a full year, the 7 days recall gives a representative picture of the main occupation of the household head. From the table we can calculate that $66.5 \%$ are farmers, and among the farmers $42 \%$ were engaged in casual labor (ganyu) during the last year. From the rawdata we have calculated that they work on average 49 days in ganyu, with the median being 30 days. Another $5 \%$ of the farmers did not report daily labor, but employment for a wage, indicating that $42 \%$ $+5 \%$ of the farmers work on other people's land, meaning that $53 \%$ of the farmers worked only their own land. Table 2 replicates Table 1, but now for all other household members. We can see that other household members to a large extent depend upon the household head, or were engaged in household work or non-paid farm work, probably on their own farm. 
Table 2: Main activity of other household members

\begin{tabular}{|l|rrr|rr|}
\hline $\begin{array}{l}\text { What has been your } \\
\text { main activity during } \\
\text { the past 7 days? }\end{array}$ & \multicolumn{2}{|l|}{$\begin{array}{l}\text { At any time in past } 12 \text { mos. } \\
\text { Were you employed for a wage? }\end{array}$} & No & Total & Y last 12 mos. Did you engage \\
in casual (ganyu) labor? & Yes \\
\hline Farmer(Mlimi) & 322 & 7846 & 8186 & 2597 & 5592 \\
Employee & 259 & 28 & 287 & 59 & 226 \\
Family business worker & 5 & 246 & 251 & 53 & 198 \\
Self employed & 13 & 130 & 143 & 30 & 112 \\
Employer & 7 & 2 & 9 & 1 & 8 \\
Unemployed & 21 & 114 & 135 & 54 & 80 \\
Non worker & 5 & 252 & 257 & 58 & 198 \\
Homeworker & 70 & 2447 & 2517 & 572 & 1942 \\
Student & 42 & 5627 & 5669 & 1055 & 4606 \\
Other & 28 & 560 & 588 & 221 & 370 \\
No response & 12 & 7164 & 7176 & 176 & 6979 \\
\hline Total & 784 & 24434 & 25218 & 4858 & 20311 \\
\hline
\end{tabular}

The information this far is on the main activity of each person. Time-use data for the last 7 days give information on the diversification of activities for all household members, see Table 3.

Table 3: Diversification among people of age 5+

\begin{tabular}{|c|c|c|c|c|c|c|}
\hline \multirow[b]{2}{*}{ Activity } & \multicolumn{3}{|c|}{ Household head } & \multicolumn{3}{|c|}{ Other household members } \\
\hline & Obs & Hours & $\%$ active & Obs & Hours & $\%$ active \\
\hline Agriculture, livestock, fishing & 8962 & 17.0 & 74.0 & 24833 & 8.6 & 50.8 \\
\hline Run household business & 8962 & 4.0 & 17.2 & 24831 & 0.7 & 4.2 \\
\hline Help in household business & 8960 & 0.3 & 2.1 & 24831 & 0.3 & 2.6 \\
\hline Casual labor & 8960 & 2.7 & 16.3 & 24829 & 0.8 & 6.5 \\
\hline Wage work & 8959 & 5.2 & 12.9 & 24834 & 0.5 & 1.5 \\
\hline Any of the above & 8958 & 29.2 & 91.8 & 24863 & 10.9 & 53.4 \\
\hline
\end{tabular}

Relative to the total time spent on income generating activities, other household members spend more time in agriculture than the household head, 8.6 hours (79\%) out of 10.9 hours, as compared to 17 hours (58\%) out of 29.2 hours for the household head. So, there is basically no diversification among the other household members, if they work they work in agriculture. For the household head there is more diversification, even though as many as $47 \%$ were only active in agriculture. Household business, wage- and casual labor are the activities that supplement agriculture. The lack of diversification within the households reflects the fact that the definition of household appears to be quite strict, and does not include the extended family, as illustrated in Table 4. 
Table 4: Household composition

\begin{tabular}{|l|r|r|}
\hline Relation & Frequency & Percent \\
\hline Head & 9100 & 21.32 \\
Wife/Husband & 6690 & 15.68 \\
Children & 20585 & 48.24 \\
Grandchildren & 3704 & 8.68 \\
Niece/Nephew & 716 & 1.68 \\
Father/Mother & 239 & 0.56 \\
Sister/Brother & 624 & 1.46 \\
Grandfather/Mother & 68 & 0.16 \\
Son/Daughter-in-law & 238 & 0.56 \\
Brother/Sister in-law & 318 & 0.75 \\
Father/Mother in-law & 81 & 0.19 \\
Other relative & 110 & 0.26 \\
Servant or servant's relative & 147 & 0.34 \\
Lodger/Lodger's relative & 4 & 0.01 \\
Other non-relative & 31 & 0.07 \\
Other & 19 & 0.04 \\
\hline Total & 42674 & 100 \\
\hline
\end{tabular}

We can see that some grandchildren are included, but very few parents, which indicate that people in Malawi separate from their parents when they get married. We do not know whether this classification reflects the local definition of households, but this is the definition applied in the survey, and is thus what we will have to use. We now go on to specify livelihood strategies based on the activities of all household members, see Table 5. We here include activities from Table 3 that lasted for at least 10 hours during those seven days.

Table 5: Livelihood strategies for the households

\begin{tabular}{|l|r|r|}
\hline Strategy & Frequency & Proportion \\
\hline No activity & 946 & $10.4 \%$ \\
Only agriculture & 4026 & $44.2 \%$ \\
Only hhbus & 379 & $4.2 \%$ \\
Only casual & 253 & $2.8 \%$ \\
Only wage & 471 & $5.2 \%$ \\
Agri+hhbus & 833 & $9.2 \%$ \\
Agri+casual & 946 & $10.4 \%$ \\
Agri+wage & 562 & $6.2 \%$ \\
Other & 684 & $7.5 \%$ \\
\hline Total & 9100 & $100 \%$ \\
\hline
\end{tabular}

As we can see, there is some diversification. Approximately $37 \%$ of the households with some activity have more than one activity, in most cases in combination with agriculture. The remaining $63 \%$ are active in only one of the five categories, and among these, $78 \%$ are active in agriculture. So, agriculture is the dominating unilateral activity, and if people diversify it is in most cases in combination with agriculture. And we also know that within agriculture maize is the dominating crop.

Landholding is a potential determinant of occupational choice. We measure landholding as the reported area of the plots under control by the household that is cultivated during the wet-season. The majority of these plots are inherited (55\%), while others are granted by local leaders $(22 \%)$, or received through the family or the spouse (21\%), while the remaining $2 \%$ are purchased. Standard units are applied as measurements, except for 22 out of the 19300 plots, and we omit these 22 plots. 
For the remaining we re-calculate the size into acres, which is the most common unit ${ }^{2}$. As land sales are very limited it is not an option to use land values. Only 8230 households report cultivated landholdings during the wet-season, and we assume zero land for the remaining 870 households. The land distribution is described in Table 6.

Table 6: Land-distribution

\begin{tabular}{|l|c|c|c|}
\hline Size (acres) & Frequency & Share (\%) & Cumulative (\%) \\
\hline 0 & 873 & 9.6 & 9.6 \\
$0-1$ & 2163 & 23.8 & 33.4 \\
$1-2$ & 2582 & 28.4 & 61.7 \\
$2-3$ & 1627 & 17.9 & 79.6 \\
$3-4$ & 850 & 9.3 & 89.0 \\
$4-5$ & 459 & 5.0 & 94.0 \\
$5-6$ & 173 & 1.9 & 95.9 \\
$6-7$ & 110 & 1.2 & 97.1 \\
$7-8$ & 89 & 1.0 & 98.1 \\
$8-10$ & 68 & 0.7 & 98.8 \\
$10-15$ & 35 & 0.4 & 99.2 \\
$15-50$ & 31 & 0.3 & 99.6 \\
$50-500$ & 15 & 0.2 & 99.7 \\
$500-2000$ & 14 & 0.2 & 99.9 \\
$2000-5000$ & 6 & 0.1 & 99.9 \\
$5000-9800$ & 5 & 0.1 & 100.0 \\
\hline
\end{tabular}

One may believe that the very large landholdings are due to miscoding, but the increase is gradual, which indicates that the larger values are correct. The median landholding is 1.8 acres, while the mean, due to the large holdings, is 11.0 acres. Even at the 90 -percentile the landholding is only 4.5 acres. So there is a very unequal distribution of land that is due to some very large estates. Now, as pointed out in the poverty assessment by the Republic of Malawi and the World Bank (2006), the larger estates are not adequately accounted for in the data set. Furthermore, we expect the behavior of households that control large farms to differ from smallholders, and we exclude these households from the regression analysis below. As the landholdings increase gradually, it is hard to set the cutoff, but there appears to be a discontinuity at 5 acres, and we decided to exclude the $6 \%$ of the households that cultivate more than 5 acres. The 8546 (94\%) households that are included in the regression analysis have a mean landholding of 1.8 acres, and a median of 1.5 acres.

Another important explanatory variable will be primary education. Data shows that $18 \%$ of the 9100 households have at least one person with the Primary School Living Certificate (PSLC). We will use a dummy for this indicator in the regressions. Before we go on to the regression analysis we disaggregate Table 5 with respect to the independent variables that will be applied in the regression analysis. The resulting descriptive statistics are reported in Table 7.

\footnotetext{
${ }^{2} 1$ hectar $=10000$ square-meters $=2.47106$ acres
} 
Table 7: Livelihood strategies (weighted) for sub-samples (\%)

\begin{tabular}{|c|c|c|c|c|c|c|c|c|c|}
\hline & All & \multicolumn{3}{|c|}{ Household size } & \multicolumn{3}{|c|}{ Farm size (acres) } & \multicolumn{2}{|c|}{ PSLC } \\
\hline Strategy & & $1-2$ & $3-5$ & $5+$ & {$[0,1]$} & $<1,2]$ & $2+$ & yes & no \\
\hline No activity & 10.4 & 18.3 & 9.6 & 6.6 & 13.1 & 9.9 & 8.3 & 7.8 & 10.9 \\
\hline Only agriculture & 43.3 & 43.3 & 43.1 & 43.6 & 34.1 & 45.4 & 49.7 & 43.9 & 43.2 \\
\hline Only hhbus & 4.2 & 4.6 & 4.8 & 3.0 & 5.7 & 4.4 & 2.8 & 3.8 & 4.3 \\
\hline Only casual & 3.1 & 5.1 & 3.1 & 1.7 & 4.4 & 2.9 & 2.0 & 1.6 & 3.4 \\
\hline Only wage & 5.4 & 8.2 & 5.3 & 3.7 & 10.7 & 3.2 & 2.4 & 5.8 & 5.3 \\
\hline Agri+hhbus & 9.0 & 5.6 & 9.6 & 10.2 & 7.1 & 8.9 & 10.7 & 10.5 & 8.7 \\
\hline Agri+casual & 10.9 & 8.4 & 11.1 & 12.3 & 9.5 & 12.9 & 10.7 & 7.8 & 11.6 \\
\hline Agri+wage & 6.0 & 2.6 & 6.2 & 7.8 & 6.7 & 5.7 & 5.7 & 7.8 & 5.7 \\
\hline Other & 7.7 & 3.9 & 7.1 & 11.1 & 8.7 & 6.6 & 7.7 & 10.9 & 7.0 \\
\hline $\mathrm{N}$ & 9100 & 1722 & 4561 & 2817 & 3036 & 2582 & 3482 & 1649 & 7451 \\
\hline
\end{tabular}

Italic means not-significantly different.

Table 7: continued

\begin{tabular}{|l|rr|rr|rrr|}
\hline & \multicolumn{2}{|c|}{ Language } & \multicolumn{2}{c|}{ Religion } & \multicolumn{3}{c|}{ Region } \\
\hline Strategy & \multicolumn{1}{|c|}{ Chewa } & not & Muslim & not & North & Central & South \\
\hline No activity & 9.5 & 11.6 & 10.5 & 10.3 & 14.6 & 10.0 & 9.8 \\
Only agriculture & 42.2 & 44.7 & 41.1 & 43.6 & 53.5 & 45.5 & 39.2 \\
Only hhbus & 4.3 & 4.2 & 7.2 & 3.8 & 2.5 & 3.7 & 5.0 \\
Only casual & 3.5 & 2.4 & 2.2 & 3.2 & 1.3 & 3.7 & 2.9 \\
Only wage & 5.6 & 5.0 & 4.5 & 5.5 & 4.1 & 3.6 & 7.2 \\
Agri+hhbus & 8.4 & 9.9 & 12.1 & 8.5 & 8.8 & 7.5 & 10.4 \\
Agri+casual & 12.4 & 8.9 & 9.2 & 11.2 & 6.0 & 11.7 & 11.4 \\
Agri+wage & 5.8 & 6.3 & 6.0 & 6.0 & 4.4 & 5.5 & 6.9 \\
Other & 8.3 & 6.9 & 7.2 & 7.8 & 4.8 & 8.9 & 7.3 \\
\hline $\mathrm{N}$ & 4886 & 4214 & 1248 & 7852 & 1320 & 3540 & 4240 \\
\hline
\end{tabular}

Italic means not-significantly different.

As expected, larger households diversify more. We also see that as farm size increases, people tend to do only agriculture, but also to combine agriculture with household business. Thus, we have an indication that wealthy people are able to diversify into high-income activities. Interestingly, there appears to be an inverted $U$ relation between farm size and the tendency to combine agriculture with casual labor. However, if we add a second-order term in the regression analysis we do not find a similar inverted U. Returning to the descriptive statistics, if someone in the household has completed primary education, then the household tend to combine agriculture with household business, or wage labor, but not to combine agriculture with casual labor. There appear to be some cultural differences along language and religious lines, and there are regional differences, with farming-only being more common in the north, and non-farm activities being more common in the south. Now, some of these variables may be correlated, so we now go on to the multivariate analysis to investigate what are the decisive determinants of livelihood strategies at the household level. We summarize the independent variables in Table 8. 
Table 8: Variables for the regression analysis

\begin{tabular}{|l|l|}
\hline Variables & Description \\
\hline Livelihood strategy dummies & See Table 5 \\
Acres of land $\leq 5$ acres & See Table 6, median equals 1.5 acres \\
Age of household head & Median equals 4 household members \\
Gender of household head & Median equals 40 years \\
Completed primary school (PSLC) & $76 \%$ males \\
Use of Chewa language & $18 \%$ of households with at least one member \\
Muslim & $54 \%$ of households \\
Seasonal dummies & $14 \%$ of households \\
Dummies for districts & High (Oct-Jan), low (June-Sept), middle as base \\
\hline
\end{tabular}

\section{Multivariate findings}

The econometric findings, based on robust, and weighted, multinomial-logit regressions, are reported in Tables 9 -13, where the pure-agriculture strategy will be the base category. The probability weights are taken from the survey-data, and reflect a stratified-random selection procedure. We will report findings with and without district fixed effects. The first results in Tables 9 - 11 will include district dummies, which mean that we study variation in livelihood strategies within districts. In Tables 10 and 11 we split the sample in the Southern and Central regions, to see whether the explanatory variables play different roles in these regions. In Tables 12 and 13 we repeat the regional analysis, but without the district dummies. Any difference in findings compared to Tables 10 and 11 will then be due to between district variation in the importance of the determinants of livelihood strategies.

Table 9: Multinomial-Logit (weighted) regressions for smallholders ( $\leq 5$ acres)

\begin{tabular}{|c|c|c|c|c|c|c|c|}
\hline \multicolumn{8}{|c|}{ elihood strategy } \\
\hline & no-activity & hh-business & casual & wage & agri+hhbus & agri+casual & agri+wage \\
\hline totarea & $\begin{array}{l}-0.28 * * * \\
(0.04)\end{array}$ & $\begin{array}{c}-0.35^{* * *} \\
(0.06)\end{array}$ & $\begin{array}{c}-0.34^{* * *} \\
(0.07)\end{array}$ & $\begin{array}{l}-0.74 * * * \\
(0.07)\end{array}$ & $\begin{array}{c}0.00 \\
(0.03)\end{array}$ & $\begin{array}{l}-0.11^{* * *} \\
(0.03)\end{array}$ & $\begin{array}{l}-0.25^{* * *} \\
(0.04)\end{array}$ \\
\hline hhsize & $\begin{array}{l}-0.13^{* * *} \\
(0.02)\end{array}$ & $\begin{array}{c}-0.06^{* *} \\
(0.03)\end{array}$ & $\begin{array}{l}-0.14^{* * *} \\
(0.04)\end{array}$ & $\begin{array}{c}-0.06^{* *} \\
(0.03)\end{array}$ & $\begin{array}{l}0.06^{* * * *} \\
(0.02)\end{array}$ & $\begin{array}{l}0.11 * * * \\
(0.02)\end{array}$ & $\begin{array}{l}0.16^{* * * *} \\
(0.02)\end{array}$ \\
\hline age & $\begin{array}{l}0.00 \\
(0.00)\end{array}$ & $\begin{array}{l}-0.02^{* * *} \\
(0.00)\end{array}$ & $\begin{array}{l}-0.03^{* * *} \\
(0.00)\end{array}$ & $\begin{array}{l}-0.02 * * * \\
(0.00)\end{array}$ & $\begin{array}{l}-0.01 * * * \\
(0.00)\end{array}$ & $\begin{array}{l}-0.02 * * * \\
(0.00)\end{array}$ & $\begin{array}{l}-0.01 * * * \\
(0.00)\end{array}$ \\
\hline male & $\begin{array}{l}-0.77 * * * \\
(0.09)\end{array}$ & $\begin{array}{c}0.09 \\
(0.14)\end{array}$ & $\begin{array}{l}-0.33^{* *} \\
(0.17)\end{array}$ & $\begin{array}{l}0.75^{* * *} \\
(0.16)\end{array}$ & $\begin{array}{l}0.51^{* * *} \\
(0.11)\end{array}$ & $\begin{array}{c}-0.10 \\
(0.09)\end{array}$ & $\begin{array}{l}1.04 * * * \\
(0.17)\end{array}$ \\
\hline pslc & $\begin{array}{c}-0.08 \\
(0.12)\end{array}$ & $\begin{array}{l}0.06 \\
(0.16)\end{array}$ & $\begin{array}{l}-0.54^{* *} \\
(0.24)\end{array}$ & $\begin{array}{l}0.38 * * \\
(0.15)\end{array}$ & $\begin{array}{c}0.09 \\
(0.11)\end{array}$ & $\begin{array}{l}-0.42^{* * *} \\
(0.12)\end{array}$ & $\begin{array}{l}0.25^{* *} \\
(0.13)\end{array}$ \\
\hline chewa & $\begin{array}{c}-0.05 \\
(0.14)\end{array}$ & $\begin{array}{c}0.26 \\
(0.19)\end{array}$ & $\begin{array}{c}-0.14 \\
(0.21)\end{array}$ & $\begin{array}{l}0.38^{* *} \\
(0.16)\end{array}$ & $\begin{array}{c}0.20 \\
(0.13)\end{array}$ & $\begin{array}{c}0.15 \\
(0.13)\end{array}$ & $\begin{array}{c}-0.22 \\
(0.15)\end{array}$ \\
\hline muslim & $\begin{array}{c}0.24 \\
(0.18)\end{array}$ & $\begin{array}{l}0.43^{* *} \\
(0.21)\end{array}$ & $\begin{array}{c}-0.32 \\
(0.30)\end{array}$ & $\begin{array}{c}0.15 \\
(0.24)\end{array}$ & $\begin{array}{l}0.40^{* * *} \\
(0.15)\end{array}$ & $\begin{array}{c}-0.02 \\
(0.15)\end{array}$ & $\begin{array}{l}-0.05 \\
(0.20)\end{array}$ \\
\hline high & $\begin{array}{l}-1.09^{* * *} \\
(0.12)\end{array}$ & $\begin{array}{l}-0.95^{* * *} \\
(0.19)\end{array}$ & $\begin{array}{l}-0.80^{* * *} \\
(0.22)\end{array}$ & $\begin{array}{l}-0.61^{* * *} \\
(0.15)\end{array}$ & $\begin{array}{c}0.08 \\
(0.10)\end{array}$ & $\begin{array}{l}0.19^{* *} \\
(0.09)\end{array}$ & $\begin{array}{c}0.22^{*} \\
(0.12)\end{array}$ \\
\hline low & $\begin{array}{l}0.37 * * * \\
(0.09)\end{array}$ & $\begin{array}{l}0.43^{* * *} \\
(0.13)\end{array}$ & $\begin{array}{l}0.62^{* * *} \\
(0.15)\end{array}$ & $\begin{array}{l}0.35^{* * *} \\
(0.12)\end{array}$ & $\begin{array}{l}0.21^{* *} \\
(0.10)\end{array}$ & $\begin{array}{c}-0.15 \\
(0.10)\end{array}$ & $\begin{array}{c}0.14 \\
(0.12)\end{array}$ \\
\hline
\end{tabular}

$\mathrm{N}=$ 8546. Pseudo $\mathrm{R} 2=0.1006$. Robust standard errors in parentheses.

Dummies for district included but not reported.

*** Significant at the $1 \%$ level

** $\quad$ Significant at the $5 \%$ level

* $\quad$ Significant at the $10 \%$ level

As we may expect, farming-only is a more likely livelihood strategy the more land the household control, which explains the significantly negative coefficient for total-area for (almost) all other 
strategies. But there is some indication in the data that for the $10 \%$ largest of these farms, the probability of having wage employment or doing household business is increasing with land-size ${ }^{3}$. This indicates that the wealthiest smallholders are able to hire help for the farm and do more profitable jobs themselves.

The descriptive finding that larger households diversify more is significant also when we control for other variables. The older is the household head, the less likely it is that the household do non-farm activities, which implicates that younger people are more likely to find non-farm jobs, and when they do so they establish their own household. Female headed households are more likely to do only casual labor, or being economically in-active. As we may expect, household where someone has completed primary school are more likely to have a household member with a salaried job (which they may combine with agriculture) ${ }^{4}$. There also appear to be some variation between ethnic and religious groups. People from the Chewa community are more likely to have a salaried job, while people from the Muslim community are more likely to do household business that they may combine with agriculture. Finally we find the expected seasonal variation, with non-farm activities being more common in the low season for agriculture.

Now we may expect to find important regional variation in the determinants of livelihood strategies. Malawi is divided into three geographical regions. As many as $92 \%$ of the people in the Central region use the Chewa language, and we may thus expect variation in the role of this socio-cultural factor between regions. As few people live in the north, we repeat the regressions for the Central and Southern sub-samples, in Tables 10 and 11.

Table 10: Multinomial-Logit (weighted) regressions for smallholders ( $\leq 5$ acres), Central

\begin{tabular}{|l|l|l|l|l|l|l|l|}
\hline \multicolumn{2}{|c|}{ Dependent variable: Livelihood strategy vs. only-agriculture. } \\
\hline & no-activity & hh-business & casual & wage & agri+hhbus & agri+casual & agri+wage \\
\hline totarea & $-0.31^{* * *}$ & $-0.43^{* * *}$ & $-0.52^{* * *}$ & $-0.93^{* * *}$ & -0.02 & $-0.20^{* * *}$ & $-0.24^{* * *}$ \\
& $(0.06)$ & $(0.09)$ & $(0.08)$ & $(0.12)$ & $(0.06)$ & $(0.05)$ & $(0.07)$ \\
hhsize & $-0.18^{* * *}$ & -0.07 & -0.08 & -0.04 & 0.05 & $0.11^{* * *}$ & $0.13^{* * *}$ \\
& $(0.04)$ & $(0.05)$ & $(0.05)$ & $(0.05)$ & $(0.03)$ & $(0.03)$ & $(0.03)$ \\
age & 0.00 & $-0.02^{* * *}$ & $-0.02^{* * *}$ & -0.01 & $-0.01^{* *}$ & $-0.02^{* * *}$ & $-0.01^{* *}$ \\
& $(0.00)$ & $(0.01)$ & $(0.01)$ & $(0.01)$ & $(0.00)$ & $(0.00)$ & $(0.01)$ \\
male & $-0.78^{* * *}$ & 0.04 & $-0.66^{* * *}$ & $0.48^{*}$ & $0.47^{* *}$ & -0.05 & $0.83^{* * *}$ \\
& $(0.14)$ & $(0.23)$ & $(0.23)$ & $(0.29)$ & $(0.21)$ & $(0.15)$ & $(0.28)$ \\
pslc & -0.32 & -0.34 & -0.51 & $0.57^{* *}$ & 0.10 & $-0.43^{* *}$ & 0.03 \\
& $(0.21)$ & $(0.29)$ & $(0.33)$ & $(0.24)$ & $(0.19)$ & $(0.18)$ & $(0.21)$ \\
chewa & $-0.53^{* *}$ & -0.42 & -0.53 & $-0.67^{* *}$ & 0.21 & 0.04 & -0.17 \\
& $0.26)$ & $(0.36)$ & $(0.35)$ & $(0.31)$ & $(0.30)$ & $(0.26)$ & $(0.35)$ \\
muslim & 0.01 & 0.52 & -0.75 & -0.73 & -0.07 & 0.01 & -0.18 \\
& $(0.34)$ & $(0.40)$ & $(0.62)$ & $(0.50)$ & $(0.34)$ & $(0.25)$ & $(0.46)$ \\
high & $-1.04^{* * *}$ & $-0.86^{* * *}$ & $-1.11^{* * *}$ & -0.22 & -0.24 & -0.09 & 0.27 \\
& $(0.19)$ & $(0.28)$ & $(0.31)$ & $(0.27)$ & $(0.17)$ & $(0.14)$ & $(0.20)$ \\
low & $0.622^{* * *}$ & $0.62^{* * *}$ & $0.70^{* * *}$ & $0.97^{* * *}$ & 0.08 & $-0.56^{* * *}$ & 0.24 \\
& $(0.14)$ & $(0.21)$ & $(0.21)$ & $(0.23)$ & $(0.17)$ & $(0.16)$ & $(0.21)$ \\
\hline
\end{tabular}

$\mathrm{N}=$ 3292. Pseudo R2 $=0.0883$. Robust standard errors in parentheses.

Dummies for district included but not reported.

*** Significant at the $1 \%$ level

** $\quad$ Significant at the $5 \%$ level

* $\quad$ Significant at the $10 \%$ level

\footnotetext{
${ }^{3}$ We added a second-order effect for land-size which for the pure household business, pure wage, and agriculture and wage strategies imply a U-shaped probability function with a minimum at 3.3 (only wage), 3.8 and 4.3 (only household business) acres, with respectively 15, 5 and $5 \%$ of the smallholders being on the upward sloping part. In particular for the salaried job strategies the finding appears to be robust, as it also turns up in probit models, and also in models where land is the only explanatory variable. But note that the probabilities will still be higher at the lower end as the U-function stops at 5 acres.

${ }^{4}$ We will use the term salaried job for wage employment to remind the reader that this will tend to be more attractive jobs than casual labor, although there are some regional differences in the type of wage employment as we will discuss below.
} 
There are some minor differences between the Central region sub-sample and the full sample, with the main difference being that Chewa households are no longer more likely to have a salaried job, they are actually less likely to have such a job. This is as expected. In the Central region almost all people are in this group, and those who do not have the Chewa language as their mother tongue may have moved here precisely to get a salaried job near the capital city of Lilongwe. We also note that for salaried jobs age is no longer a problem in this region. Note that a salaried job is here any job for a wage or salary that is not ganyu (casual labor). So the category includes professionals, as well as manual labor. In the Central region relatively more professionals, while in the Southern region many of them are manual laborers, which may also contribute to differences in the sub-sample estimates.

Table 11: Multinomial-Logit (weighted) regressions for smallholders ( $\leq 5$ acres), South

\begin{tabular}{|c|c|c|c|c|c|c|c|}
\hline \multicolumn{8}{|c|}{ variable: Livelihood strategy vs. only-agriculture. } \\
\hline & no-activity & hh-business & casual & wage & agri+hhbus & agri+casual & agri+wage \\
\hline totarea & $\begin{array}{l}-0.27^{* * *} \\
(0.06)\end{array}$ & $\begin{array}{c}-0.24 * * * \\
(0.08)\end{array}$ & $\begin{array}{c}-0.10 \\
(0.10)\end{array}$ & $\begin{array}{c}-0.58^{* * *} \\
(0.09)\end{array}$ & $\begin{array}{c}0.05 \\
(0.05)\end{array}$ & $\begin{array}{c}-0.03 \\
(0.05)\end{array}$ & $\begin{array}{l}-0.20 * * * \\
(0.06)\end{array}$ \\
\hline hhsize & $\begin{array}{l}-0.10^{* * *} \\
(0.03)\end{array}$ & $\begin{array}{c}-0.07 \\
(0.04)\end{array}$ & $\begin{array}{l}-0.25^{* * * *} \\
(0.08)\end{array}$ & $\begin{array}{c}-0.09 * * \\
(0.04)\end{array}$ & $\begin{array}{c}0.05^{*} \\
(0.03)\end{array}$ & $\begin{array}{l}0.11^{* * *} \\
(0.03)\end{array}$ & $\begin{array}{l}0.16^{* * *} \\
(0.03)\end{array}$ \\
\hline age & $\begin{array}{c}0.00 \\
(0.00)\end{array}$ & $\begin{array}{l}-0.02^{* * *} \\
(0.01)\end{array}$ & $\begin{array}{l}-0.03^{* * * *} \\
(0.01)\end{array}$ & $\begin{array}{l}-0.03^{* * *} \\
(0.00)\end{array}$ & $\begin{array}{l}-0.01^{* * *} \\
(0.00)\end{array}$ & $\begin{array}{l}-0.02^{* * *} \\
(0.00)\end{array}$ & $\begin{array}{l}-0.02 * * * \\
(0.00)\end{array}$ \\
\hline male & $\begin{array}{l}-0.81^{* * *} \\
(0.14)\end{array}$ & $\begin{array}{c}0.14 \\
(0.19)\end{array}$ & $\begin{array}{l}0.07 \\
(0.26)\end{array}$ & $\begin{array}{l}0.94 * * * \\
(0.21)\end{array}$ & $\begin{array}{l}0.57^{* * *} \\
(0.15)\end{array}$ & $\begin{array}{c}-0.11 \\
(0.13)\end{array}$ & $\begin{array}{l}1.14^{* * *} \\
(0.22)\end{array}$ \\
\hline pslc & $\begin{array}{c}-0.05 \\
(0.21)\end{array}$ & $\begin{array}{l}0.09 \\
(0.24)\end{array}$ & $\begin{array}{c}-0.64 \\
(0.43)\end{array}$ & $\begin{array}{c}0.32 \\
(0.22)\end{array}$ & $\begin{array}{c}0.08 \\
(0.17)\end{array}$ & $\begin{array}{l}-0.39 * * \\
(0.18)\end{array}$ & $\begin{array}{c}0.28 \\
(0.19)\end{array}$ \\
\hline chewa & $\begin{array}{c}0.16 \\
(0.17)\end{array}$ & $\begin{array}{l}0.50^{* *} \\
(0.21)\end{array}$ & $\begin{array}{c}-0.05 \\
(0.27)\end{array}$ & $\begin{array}{l}0.58^{* * * *} \\
(0.19)\end{array}$ & $\begin{array}{c}0.22 \\
(0.16)\end{array}$ & $\begin{array}{c}0.21 \\
(0.16)\end{array}$ & $\begin{array}{c}-0.25 \\
(0.17)\end{array}$ \\
\hline muslim & $\begin{array}{c}0.41^{*} \\
(0.22)\end{array}$ & $\begin{array}{l}0.47^{* *} \\
(0.24)\end{array}$ & $\begin{array}{c}-0.18 \\
(0.37)\end{array}$ & $\begin{array}{c}0.40 \\
(0.29)\end{array}$ & $\begin{array}{l}0.50^{* * *} \\
(0.19)\end{array}$ & $\begin{array}{c}-0.08 \\
(0.19)\end{array}$ & $\begin{array}{c}-0.04 \\
(0.23)\end{array}$ \\
\hline high & $\begin{array}{l}-1.47^{* * *} \\
(0.22)\end{array}$ & $\begin{array}{l}-1.21^{* * *} \\
(0.29)\end{array}$ & $\begin{array}{c}-0.42 \\
(0.32)\end{array}$ & $\begin{array}{l}-0.72^{* * *} \\
(0.20)\end{array}$ & $\begin{array}{l}0.32^{* *} \\
(0.15)\end{array}$ & $\begin{array}{l}0.58^{* * *} \\
(0.14)\end{array}$ & $\begin{array}{c}0.21 \\
(0.17)\end{array}$ \\
\hline low & $\begin{array}{l}-0.15 \\
(0.14)\end{array}$ & $\begin{array}{c}0.16 \\
(0.17)\end{array}$ & $\begin{array}{c}0.24 \\
(0.24)\end{array}$ & $\begin{array}{c}-0.09 \\
(0.16)\end{array}$ & $\begin{array}{c}0.20 \\
(0.14)\end{array}$ & $\begin{array}{c}0.13 \\
(0.14)\end{array}$ & $\begin{array}{l}-0.00 \\
(0.16)\end{array}$ \\
\hline
\end{tabular}

$\mathrm{N}=4051$. Pseudo $\mathrm{R} 2=0.1068$. Robust standard errors in parentheses.

Dummies for district included but not reported.

*** $\quad$ Significant at the $1 \%$ level

** $\quad$ Significant at the $5 \%$ level

* $\quad$ Significant at the $10 \%$ level

For the Southern region there are no major differences as compared to the full sample. Some results are no longer significant, but this is probably only due to a smaller sample, and in particular so for the pure casual labor strategy where both the land-size, gender and education effects are no longer significant. The lack of importance of land-size is there also for the combined farming-casual labor strategy which may indicate a real difference from the full sample, which indicates that casual labor is a complementary activity at all farm-sizes in the south. It also appears that Chewa households are more likely to do household business in the south.

Next, we remove the district dummies to see whether there will be any major change in the parameters for both sub-samples. Any such change will be due to between district variation (but still within region) in the determinants of livelihood strategies. 
Table 12: Multinomial-Logit (weighted) regressions for smallholders ( $\leq 5$ acres), Central

\begin{tabular}{|l|l|l|l|l|l|l|l|}
\hline \multicolumn{2}{|c|}{ Dependent variable: Livelihood strategy vs. only-agriculture. } \\
\hline & no-activity & hh-business & casual & wage & agri+hhbus & agri+casual & agri+wage \\
\hline totarea & $-0.30^{* * *}$ & $-0.43^{* * *}$ & $-0.51^{* * *}$ & $-0.98^{* * *}$ & -0.04 & $-0.21^{* * *}$ & $-0.24^{* * *}$ \\
& $(0.06)$ & $(0.08)$ & $(0.09)$ & $(0.13)$ & $(0.05)$ & $(0.05)$ & $(0.07)$ \\
hhsize & $-0.17^{* * *}$ & -0.06 & $-0.09^{*}$ & -0.04 & $0.06^{*}$ & $0.11^{* * *}$ & $0.13^{* * *}$ \\
& $(0.04)$ & $(0.05)$ & $(0.05)$ & $(0.05)$ & $(0.03)$ & $(0.03)$ & $(0.03)$ \\
age & 0.00 & $-0.02^{* * *}$ & $-0.02^{* * *}$ & -0.01 & $-0.01^{* *}$ & $-0.02^{* * *}$ & $-0.01^{* *}$ \\
& $(0.00)$ & $(0.01)$ & $(0.01)$ & $(0.01)$ & $(0.00)$ & $(0.00)$ & $(0.01)$ \\
male & $-0.78^{* * *}$ & -0.03 & $-0.59^{* * *}$ & $0.65^{* *}$ & $0.44^{* *}$ & -0.05 & $0.85^{* * *}$ \\
& $(0.14)$ & $(0.23)$ & $(0.23)$ & $(0.28)$ & $(0.20)$ & $(0.15)$ & $(0.28)$ \\
pslc & $-0.37^{*}$ & -0.33 & $-0.53^{*}$ & $0.63^{* * *}$ & 0.11 & $-0.40^{* *}$ & 0.01 \\
& $(0.21)$ & $(0.29)$ & $(0.32)$ & $(0.23)$ & $(0.18)$ & $(0.18)$ & $(0.21)$ \\
chewa & $-0.42^{*}$ & -0.32 & -0.49 & $-1.31^{* * *}$ & 0.15 & 0.14 & -0.27 \\
& $0.23)$ & $(0.33)$ & $(0.33)$ & $(0.28)$ & $(0.29)$ & $(0.24)$ & $(0.32)$ \\
muslim & 0.38 & 0.22 & -1.00 & $-1.07^{* *}$ & -0.10 & 0.14 & -0.48 \\
& $(0.31)$ & $(0.37)$ & $(0.61)$ & $(0.48)$ & $(0.33)$ & $(0.23)$ & $(0.42)$ \\
high & $-0.98^{* * *}$ & $-0.90^{* * *}$ & $-0.98^{* * *}$ & -0.12 & -0.27 & -0.12 & 0.31 \\
& $(0.19)$ & $(0.28)$ & $(0.30)$ & $(0.27)$ & $(0.17)$ & $(0.13)$ & $(0.20)$ \\
& $0.655^{* * *}$ & $0.66^{* * *}$ & $0.67 * * *$ & $1.00^{* * *}$ & 0.09 & $-0.51^{* * *}$ & 0.26 \\
& $0.14)$ & $(0.21)$ & $(0.21)$ & $(0.23)$ & $(0.17)$ & $(0.15)$ & $(0.21)$ \\
cons & 0.55 & -0.30 & 0.76 & -0.32 & $-2.02^{* * *}$ & $-0.63^{*}$ & $-2.46^{* * *}$ \\
& $(0.33)$ & $(0.51)$ & $(0.51)$ & $(0.53)$ & $(0.42)$ & $(0.35)$ & $(0.47)$ \\
\hline
\end{tabular}

$\mathrm{N}=$ 3292. Pseudo R2 $=0.0687$. Robust standard errors in parentheses.

*** Significant at the $1 \%$ level

** $\quad$ Significant at the $5 \%$ level

* $\quad$ Significant at the $10 \%$ level

The only essential difference in the Central region is for the pure salaried job strategy, where the Chewa and Muslim dummies are now more important. This means that although there were differences between, for example, Muslims and other households within districts, there are larger differences between districts. So some districts have a relatively high number of households from the Muslim and Chewa communities that are not engage in salaried work (effect that are otherwise picked up by the district dummies). This district variation is not surprising and probably depends on the distance to the capital city. 
Table 13: Multinomial-Logit (weighted) regressions for smallholders ( $\leq 5$ acres), South

\begin{tabular}{|l|l|l|l|l|l|l|l|}
\hline \multicolumn{2}{|c|}{ Dependent variable: Livelihood strategy vs. only-agriculture. } \\
\hline & no-activity & hh-business & casual & wage & agri+hhbus & agri+casual & agri+wage \\
\hline totarea & $-0.24^{* * *}$ & $-0.22^{* * *}$ & -0.11 & $-0.65^{* * *}$ & 0.05 & -0.03 & $-0.21^{* * *}$ \\
& $(0.06)$ & $(0.08)$ & $(0.11)$ & $(0.10)$ & $(0.04)$ & $(0.04)$ & $(0.06)$ \\
hhsize & $-0.12^{* * *}$ & $-0.08^{*}$ & $-0.26^{* * *}$ & $-0.09^{* *}$ & $0.05^{*}$ & $0.10^{* * *}$ & $0.15^{* * *}$ \\
& $(0.03)$ & $(0.04)$ & $(0.07)$ & $(0.04)$ & $(0.03)$ & $(0.03)$ & $(0.03)$ \\
age & 0.00 & $-0.01^{* * *}$ & $-0.03^{* * *}$ & $-0.02^{* * *}$ & $-0.01^{* * *}$ & $-0.02^{* * *}$ & $-0.02^{* * *}$ \\
& $0.00)$ & $(0.01)$ & $(0.01)$ & $(0.00)$ & $(0.00)$ & $(0.00)$ & $(0.00)$ \\
male & $-0.75^{* * *}$ & 0.14 & 0.09 & $1.02^{* * *}$ & $0.58^{* * *}$ & -0.10 & $1.19^{* * *}$ \\
& $(0.13)$ & $(0.19)$ & $(0.25)$ & $(0.21)$ & $(0.15)$ & $(0.13)$ & $(0.22)$ \\
pslc & -0.07 & 0.15 & $-0.71^{*}$ & 0.12 & 0.12 & $-0.38^{* *}$ & 0.19 \\
& $(0.20)$ & $(0.23)$ & $(0.42)$ & $(0.20)$ & $(0.16)$ & $(0.18)$ & $(0.18)$ \\
chewa & 0.13 & $0.56^{* * *}$ & 0.12 & $0.60^{* * *}$ & 0.14 & $0.322^{* * *}$ & -0.07 \\
& $0.14)$ & $(0.17)$ & $(0.22)$ & $(0.16)$ & $(0.13)$ & $(0.12)$ & $(0.15)$ \\
muslim & 0.13 & $0.74 * * *$ & -0.29 & -0.29 & $0.38^{* * *}$ & $-0.39^{* * *}$ & -0.14 \\
& $(0.14)$ & $(0.17)$ & $(0.26)$ & $(0.19)$ & $(0.13)$ & $(0.15)$ & $(0.17)$ \\
high & $-1.38^{* * *}$ & $-1.14^{* * *}$ & -0.35 & $-0.67 * * *$ & $0.29^{* *}$ & $0.55^{* * *}$ & 0.22 \\
& $(0.21)$ & $(0.28)$ & $(0.32)$ & $(0.19)$ & $(0.15)$ & $(0.14)$ & $(0.17)$ \\
& -0.15 & 0.21 & 0.27 & -0.07 & 0.18 & 0.12 & -0.01 \\
low cons & $0.13)$ & $(0.17)$ & $(0.24)$ & $(0.16)$ & $(0.13)$ & $(0.14)$ & $(0.16)$ \\
& -0.12 & $-1.24 * * *$ & -0.40 & -0.40 & $-1.92^{* * *}$ & $-1.01^{* * *}$ & $-2.37 * * *$ \\
& $(0.24)$ & $(0.33)$ & $(0.49)$ & $(0.34)$ & $(0.25)$ & $(0.23)$ & $(0.30)$ \\
\hline
\end{tabular}

$\mathrm{N}=4051$. Pseudo $\mathrm{R} 2=0.0615$. Robust standard errors in parentheses.

*** Significant at the $1 \%$ level

** $\quad$ Significant at the $5 \%$ level

* $\quad$ Significant at the $10 \%$ level

In the Southern region the major difference is for the combination of agriculture and casual labor strategy, where again the Chewa and Muslim dummies are more important when we allow for between district variation. Again the implication is that in some Southern districts (such as Mwanza) there are many Chewa speaking households that combine agriculture with casual labor, while there are few Muslims in the same districts. The Muslims rather live in districts (such as Mangochi) where many of them do household businesses.

We may now summarize the findings, where some are as expected. The pure farming strategy is more likely the larger is the farm, and combination of farming with other activities is more likely in larger households. Furthermore, younger people are more likely to find non-farm jobs, and completed primary education increases the chance of getting a salaried job. Finally, there are some differences between ethnic and religious groups, with households from the Muslim community being more likely to be engaged in household businesses. When it comes to regional differences, we find that Chewa households in the Southern region are more likely to have salaried jobs, while the opposite is the case in the Central region, where the Chewa speakers are in majority. The latter effect is even stronger if we allow for between districts variation within the Central region.

\section{Conclusions}

As we may expect, some resources are needed to be able to conduct non-farm economic activities. It appears that larger landholdings, meaning more than 3 acres, allow some households to switch away from agriculture. However, the main effect is that households with less land, or more household members, will find other occupations. For some of them this can be a pathway out of poverty. We also find that young people are better able to find non-farm occupations. Furthermore, we find that completed primary schooling appears not to increase the probability of livelihood diversification, but makes it more likely to get salaried work. We conclude that the relatively equal land-distribution among small-holders in Malawi still allows some wealthier households, and force others, to do non- 
farm activities. This, in turn, may lead to small-scale development within villages. Furthermore, investment in primary education, taking into account the low initial level of education in Malawi, is probably a good investment for rural development. And, we find it promising that younger people are able to find non-farm livelihoods.

There appears to be some differences between socio-cultural groups. Muslims, who live mostly in the Southern region, are more likely to do household business, while people from the Chewa community appear to have more livelihood options in the Southern region than in the Central region where they are the dominant group. In general, there is more diversification and non-agricultural livelihoods in the Southern region, where also poverty is higher as reported by the Republic of Malawi and the World Bank (2006). It appears that lack of agricultural opportunities in the south imply that households do, maybe more low-status, salaried work and household businesses in this region. For some households this may still be a way out of poverty. The policy implications for the poorer Southern region are not obvious. But, to the extent feasible, the farmers may learn from the more productive farmers in the Central region, where there is more emphasize on cash-crop production, and also possibly combine agriculture with household businesses to a larger extent. For a good analysis of the prospects for rural development in the Southern region see Orr and Orr (2002).

\section{References}

Barrett, C.B., Bezuneh, M. and Aboud, A. (2001). "Income Diversification, Poverty Traps and Policy Shocks in Côte d'Ivoire and Kenya." Food Policy. 26: 367-384.

Barrett, C.B., Reardon, T. and Webb, P. (2001). "Nonfarm Income Diversification and Household Livelihood Strategies in Rural Africa: Concepts, Dynamics, and Policy Implications." Food Policy. 26: 315-331.

Dorward, A., Morrison, J., Wobst, P., Lofgren, H., and Tchale, H. (2004). Modelling Pro-Poor Agricultural Growth Strategies in Malawi: Lessons for Policy and Analysis. African Development and Poverty Reduction: The Macro-Micro Linkage. Forum Paper, 12-15 October 2004, South Africa.

Ellis, F., Kutengule, M., and Nyasulu, A. (2003). "Livelihoods and Rural Poverty Reduction in Malawi". World Development. 31(9): 1495-1510.

IHS2 (2005). Malawi Second Integrated Household Survey. Basic Information Document. Available at: www.worldbank.org/lsms.

Jul-Larsen, E. and Mvula, P. (2009). "Security for Many or Surplus for the Few? Customary Tenure and Social Differentiation in Southern Malawi". Journal of Southern African Studies. 35(1): 175190.

Orr, A. and Orr, S. (2002). Agriculture and Micro Enterprise in Malawi's Rural South. Agren Network Paper 119. Available at: www.odi.org.uk/agren.

Republic of Malawi and the World Bank (2006). Malawi. Poverty and Vulnerability Assessment. Investing in Our Future. Draft June 2006. 

Chr. Michelsen Institute

Bergen, Norway

Tel: +4755574000

Fax: +4755574166

cmi@cmi.no

WwW.cmi.no 


\section{SUMMARY}

This is a background paper on livelihood strategies in rural Malawi in general. Livelihood strategies are identified at the household level as a function of assets held, using survey data. Only endowments that are likely to be predetermined are included in the empirical analysis. As expected, land, household size, age and primary education turn out to be important determinants of livelihood strategies. It appears that the relatively equal landdistribution among small-holders in Malawi still allows some wealthier households, and force others, to do non-farm activities. This, in turn, may lead to small-scale development within villages. Furthermore, investment in primary education, taking into account the low initial level of education in Malawi, is probably a good investment for rural development. And, we find it promising that younger people are able to find non-farm livelihoods. It also turns out to be significant regional variation in livelihood strategies, with more diversification in the Southern region, and with regional variation in the role of ethnic and religious identity as determinants of livelihood strategies. It appears that lack of agricultural opportunities in the south imply that households do, maybe more low-status, salaried work and household businesses in this region. For some households this may still be a way out of poverty. The policy implications for the poorer Southern region are not obvious. But, to the extent feasible, the farmers may learn from the more productive farmers in the Central region, where there is more emphasize on cash-crop production.

\section{Printed version: ISSN 0804-3639}

Electronic version: ISSN 1890-5048

Printed version: ISBN 978-82-8062-361-4

Electronic version: ISBN 978-82-8062-362-1

Chr. Michelsen Institute (CMI) is an independent, non-profit research institution and a major international centre in policy-oriented and applied development research. Focus is on development and human rights issues and on international conditions that affect such issues. The geographical focus is Sub-Saharan Africa, Southern and Central Asia, the Middle East, the Balkans and South America.

CMI combines applied and theoretical research. CMI research intends to assist policy formulation, improve the basis for decision-making and promote public debate on international development issues. 